Journal of Nepal Agricultural Research Council

Vol. 6: 85-91, March 2020

ISSN: 2392-4535 (Print), 2392-4543 (Online)

DOI: https://doi.org/10.3126/jnarc.v6i0.28119

\title{
Evaluation of Insecticides for the Management of Litchi Fruit and Shoot Borer
}

\author{
Sudeep Kumar Upadhyay ${ }^{1}$, Sunil Aryal ${ }^{1}$, Bikash Bhusal ${ }^{1}$, and Bedanand Chaudhary ${ }^{2}$
}

${ }^{1}$ Nepal Agricultural Research Council, Entomology Division, Kathmandu, Nepal; @: sudeeppdl@gmail.com; ORCID: https://orcid.org/- 0000-0002-4237-5623; SA: sunilaryal@narc.gov.np; BB:

bhusalbikash2015@gmail.com;

${ }^{2}$ National Rice Research Program, Hardinath, Dhanusha, Nepal; bedanand.chy@gmail.com

Received 07 Sept 2019, Revised 27 Dec 2019, Accepted 14 Feb 2020, Published 17 March 2020

Scientific Editors: Jiban Shrestha, Saraswati Neupane, Subash Subedi, Manoj Thakur

Copyright (C) 2020 NARC. Permits unrestricted use, distribution and reproduction in any medium provided the original work is properly cited.

The authors declare that there is no conflict of interest.

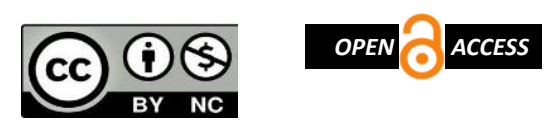

Licensed under the Creative Commons AttributionNonCommercial 4.0 International (CC BY-NC 4.0)

\section{ABSTRACT}

Litchi is an important subtropical evergreen fruit crop grown in Nepal, which have high nutritive value and refreshing taste. The Litchi growers are experiencing severe loss every year with the damage caused by several insect pests. Among them fruit and shoot borer Conopomorpha sinensis Bradley (Lepidoptera: Gracillariidae) is the one of the important insect pest. Experiments were conducted at RARS Tarahara on existing litchi orchard in RCBD design with four replication and five insecticides (Azadiractin, Chlorantraniliprole, Flubendiamide, Lambda cyhalothrin, and Dimethoate) with recommended doses in litchi orchard against $C$. sinensis during 2015 and 2016 to find out the efficient one. Among the tested insecticide chlorantraniliprole $(18.5 \% \mathrm{w} / \mathrm{w} \mathrm{SC})$ and flubendiamide $(39.35 \%$ $\mathrm{m} / \mathrm{m} \mathrm{SC}$ ) each were found to be most efficient against $C$. sinensis and could be applied at the rate of 1 $\mathrm{ml}$ per 3 liter of water when fruit size was about pea and applied 3 times with 10 days interval. This result suggested that these two insecticides could be used for the management for $C$. sinensis. Farmers may reduce the losses and increase their income with the application of these insecticides

Keywords: Conopomorpha sinensis, Chlorantraniliprole, Flubendiamide, Litchi

\section{साराशं}

लिची, नेपालको उपोष्ण जलवायुमा हुने बिशेष स्वाद रहेको तथा उच्च पोषकतत्वहरु भएको एक सदाबहार फल हो । यसको व्यावसायिक खेति नेपालको तराई भूभागमा विशेष रुपमा गरिन्छ भने यसमा भएको पोषण तत्वको महत्व र यसबाट हुने आर्थिक फाईदाको कारणले यसको विस्तार पहाडी जिल्लाहरुका उपोष्ण हावापानी भएको क्षेत्रमा पनि भएको पाईन्छ । लिची उत्पादनका प्रमुख समस्याहरु मध्ये कीराहरुले गर्दा हुने नोक्सानीको कारणले किसानहरुले व्यापक क्षति व्यर्होनु परेको छ। ती कीराहरु मध्ये पनि लिचिको फलको गवारो (Conopomorpha sinensis) प्रमुख शत्रुको रुपमा पाइएको छ। यस अध्ययनमा गवारो कीरा व्यवस्थापनको लागि बिभिन्न $y$ वटा बिषादीहरु को परिक्षण इस्वी संवत २०१ $y$ र २०१६ मा गरिएको थियो । प्राप्त नतिजा को आधारमा उक्त बिषादीहरु मध्ये क्लोरानट्रानिलीप्रोल (१६.५\% w/w SC) र फ्लुबेनडीयामाइड ३९.३५\% $\mathrm{m} / \mathrm{m}$ कमश: $१$ मिलि प्रति ३ लिटर पानीमा लिची को फल केराउ को दाना बराबर भएको बेला देखि १० दिनको फरकमा ३ पटक बोट भिज्ने गरि छर्कदा कीरा नियन्त्रण उल्लेख्य भएको पाईयो ॥

\section{INTRODUCTION}

Litchi, Litchi chinensis Sonn (Sapindaceae: Sapindales), is an important subtropical evergreen fruit crop. Litchi fruit considered as one of the best fruits due to its high nutritive value as it contains carbohydrates, vitamin A, vitamin B, vitamin C, carotenoids, phosphorus, calcium and irons polyphenols (USDA 2019, Feng et al 2015). Cultivation of litchi is widely spread in Nepal and provides livelihood opportunities to litchi growers. Nineteen districts have been prioritized as potential litchi production in Nepal (FDD 2008). In Nepal, litchi covered area and production of 6835 ha and 36992 metric ton respectively with productivity of 7.40 metric ton per ha in 2016 (MoAD 2016). 
The litchi growers are facing various biotic problems of several insect-pests such as fruit and shoot borer, litchi mite, bark eating caterpillar, leaf folder, litchi looper, litchi weevils etc., which caused severe loss to the growers (Kumar et al 2014). Among insect-pests, litchi fruit and shoot borer, Conopomorpha sinensis (Lepidoptera: Gracillariidae) is one of the major threats to litchi growers, causing severe losses to fruit as well as young shoots causing up to $24-48 \%$ and $7-70 \%$, respectively (Srivastava et al 2015, Li et al 2014). Conopomorpha sinensis adult female lays eggs on leaves, shoot, or fruits stems singly or in groups and after hatched larvae penetrate the fruits, flower, tender shoots and leaves, and feed on seed neck immediately which causes poor fruit quality and fruits drop after infestation (Waite 2005, Schulte 2007, Huang et al 1994, Manzel 2002, Tsang and Liang 2007, Kumar et al 2014, Meng et al 2018). Conopomorpha sinensis attacks litchi and Longan (Dimocarpus longan Lour.) in south East Asia and southern China (Thanh et al 2006, Tran et al 2019) and is considered as a destructive pest causing significant economic losses (Zhang et al 2011). Due to its cryptic feeding behavior and overlapping of generation, $C$. sinensis is difficult to manage (Meng et al 2018). Like other crops, insecticides particularly organophosphates and carbamates are most powerful and widely accepted chemicals for the control of pests in litchi but, excessive reliance on insecticides has posed several adverse effects such as buildup of pest resistance to insecticide, outbreak of secondary pests, harmful to non-target organisms, health hazards and problems related to environmental pollution. Menzel (2002) and Chen (2011) reported that controlling of $C$. sinensis is not particularly effective owing to its boring habit, but selective pesticide may be effective for its management. Novel insecticides like diamides having low mammalian toxicity has been reported effective against various borers (Deshmukh et al 2010, Larrain et al 2014) which were included in our study.

In this regards new generation insecticides could be an option and can be suitable to incorporate in integrated pest management program because they have selective action, are less hazardous, low mammalian toxicity (Qi and Casida 2013) and do not contaminate to the food chain in the environment (Kuldeep et al 2004). The acute oral toxicity, $\mathrm{LD}_{50}$ of flubendiamide and chlorantraniliprole fall under toxicity category III and IV with the 2000 and $5000 \mathrm{mg} / \mathrm{kg}$ respectively for human risk assessment which have low selectivity toward mammals than insects (Lahm et al 2009). Our main objective of this research was to find out the efficacy of novel insecticides with low mammalian toxicity for the management of $C$. sinensis in Litchi.

\section{MATERIALS AND METHODS}

Field experiment was conducted at eastern terai of Nepal, Regional Agricultural Research Station (RARS), Tarahara, Sunsari (26 $70^{\prime} 39^{\prime \prime} \mathrm{N}, 8^{\circ} 28^{\prime} 53^{\prime \prime} \mathrm{E}$ and 450 masl) on litchi orchard for consecutive two years during 2015 and 2016, April to May. Mean minimum and maximum temperature during the period of experiment were $23.9 \pm 0.3$ and $33.1 \pm .0 .2$ and $23.1 \pm 0.6$ and $32.5 \pm 0.2^{\circ} \mathrm{C}$ in 2015 and 2016 respectively. Experiments were conducted during fruiting stage of litchi plant (variety -Muzaffarpur). This cultivar was introduced from India which are grown in the Terai and low hills and its fruits mature from mid-May to mid-June. The variety is early maturing and color of the fruit is deep pink (Singh et al 2012). Treated litchi plants were approximately 15 years old. Different insecticide, some of having low mammalian toxicity, (Table 1) was compared with control (water sprayed). In each replication 4 trees were assigned comprising each tree for one treatment. The experiment was conducted in a randomized complete block design (RCBD) with four replications. One tree in all replication was assigned as control sprayed only with water.

Table 1. Description of different insecticide used in the experiment on litchi orchard against Conopomorpha sinensis during 2015 and 2016 Nepal

\begin{tabular}{llllll}
\hline SN Common name & \multicolumn{2}{c}{ Trade name Mode of action } & Formulation & Dose \\
\hline 1 & Azadirachtin & Nico Neem & $\mathrm{UN}^{\mathrm{b}}$ & $0.15 \% \mathrm{w} / \mathrm{w} \mathrm{EC}$ & $5 \mathrm{ml} / \mathrm{L} \mathrm{water}$ \\
\hline 2 & Chlorantraniliprole & Coragen & Rynodine receptor Modulator (RyR) & $18.5 \% \mathrm{w} / \mathrm{w} \mathrm{SC}$ & $1 \mathrm{ml} / 3 \mathrm{~L} \mathrm{water}$ \\
\hline 3 & Flubendiamide & Fame & Rynodine receptor Modulator & $39.35 \% \mathrm{~m} / \mathrm{m} \mathrm{SC}$ & $1 \mathrm{ml} / 3 \mathrm{~L} \mathrm{water}$ \\
\hline 4 & Lambda cyhalothrin & Sumo & Sodium channel modulator & $2.5 \% \mathrm{EC}$ & $1.5 \mathrm{ml} / \mathrm{L} \mathrm{water}$ \\
\hline 5 & Dimethoate & Rogar & Acetylcholinesterase inhibitor & $30 \% \mathrm{EC}$ & $1.5 \mathrm{ml} / \mathrm{L} \mathrm{water}$ \\
\hline
\end{tabular}

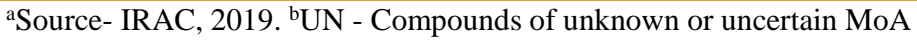


First application of the insecticides was done when the fruits were of pea size and continued for three times in 10 days interval. Randomly 100 fruits were collected from each tree after 15 days of last spraying. Collected samples were dissected and observed with hand-lens for the presence of $C$. sinensis. Damage by the larvae in the litchi fruits was confirmed by their presence. Number damaged were managed in spread sheet and converted to percent infestation which was subjected to the ANOVA analysis with Tukey's HSD post-hoc mean comparison using SPSS 2016 (SPSS 2016).

\section{RESULTS}

Mean per cent infestation of $C$. sinensis during both years showed that all the insecticides were significantly effective as compared to control. However, chlorantraniliprole was found to be best causing minimum damage in both 2015 and 2016 with the damage percentage of $12.0(P \leq 0.01)$ and $15.3(P \leq 0.01)$ respectively followed by flubendiamide (Figure 1, Figure 2). Flubendiamide treated tree incurred $C$. sinensis damage by only 22.8 and $20.0 \%$ in two consecutive year of 2015 and 2016 respectively (Figure 1, Figure 2) which were significantly effective than control. Pooled analysis $(P \leq 0.01)$ between both year also $(P \leq 0.01)$ revealed that the chlorantraniliprole is superior among all tested treatment in terms of damage percentage followed by flubendiamide (Table 2).

Table 2. Pooled damage percentage of litchi borer among treated orchards in 2015 and 2016 on Regional Agricultural Research Station (RARS), Tarahara, Sunsari

\begin{tabular}{lll}
\hline SN & Treatment & Damage $( \pm$ SE) $\%$ \\
\hline 1 & Azadirachtin & $65.25 \pm 4.17 \mathrm{c}$ \\
\hline 2 & Chlorantraniliprole & $13.61 \pm 2.54 \mathrm{a}$ \\
\hline 3 & Flubendiamide & $21.38 \pm 2.06 \mathrm{a}$ \\
\hline 4 & Lambda cyhalothrin & $46.38 \pm 5.76 \mathrm{~b}$ \\
\hline 5 & Dimethoate & $49.13 \pm 4.10 \mathrm{~b}$ \\
\hline 6 & Control & $87.13 \pm 2.62 \mathrm{~d}$ \\
\hline
\end{tabular}

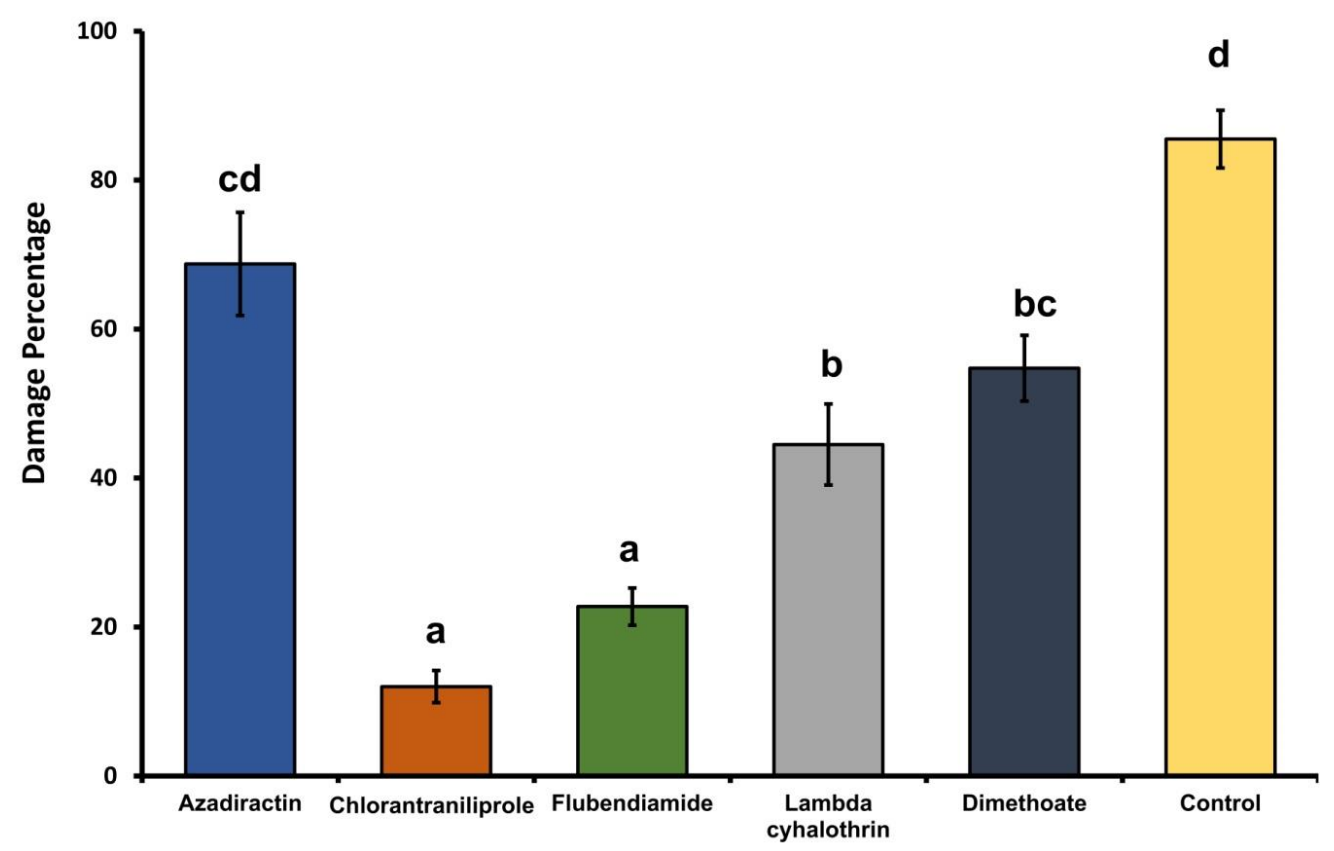

Figure 1. Mean percentage damage caused by Conopomorpha sinensis on Litchi in 2015 on Regional Agricultural Research Station (RARS), Tarahara, Sunsari (Bars with same letter for each treatment represents the damage was not significantly difference at $P<0.05 \%$ ). 


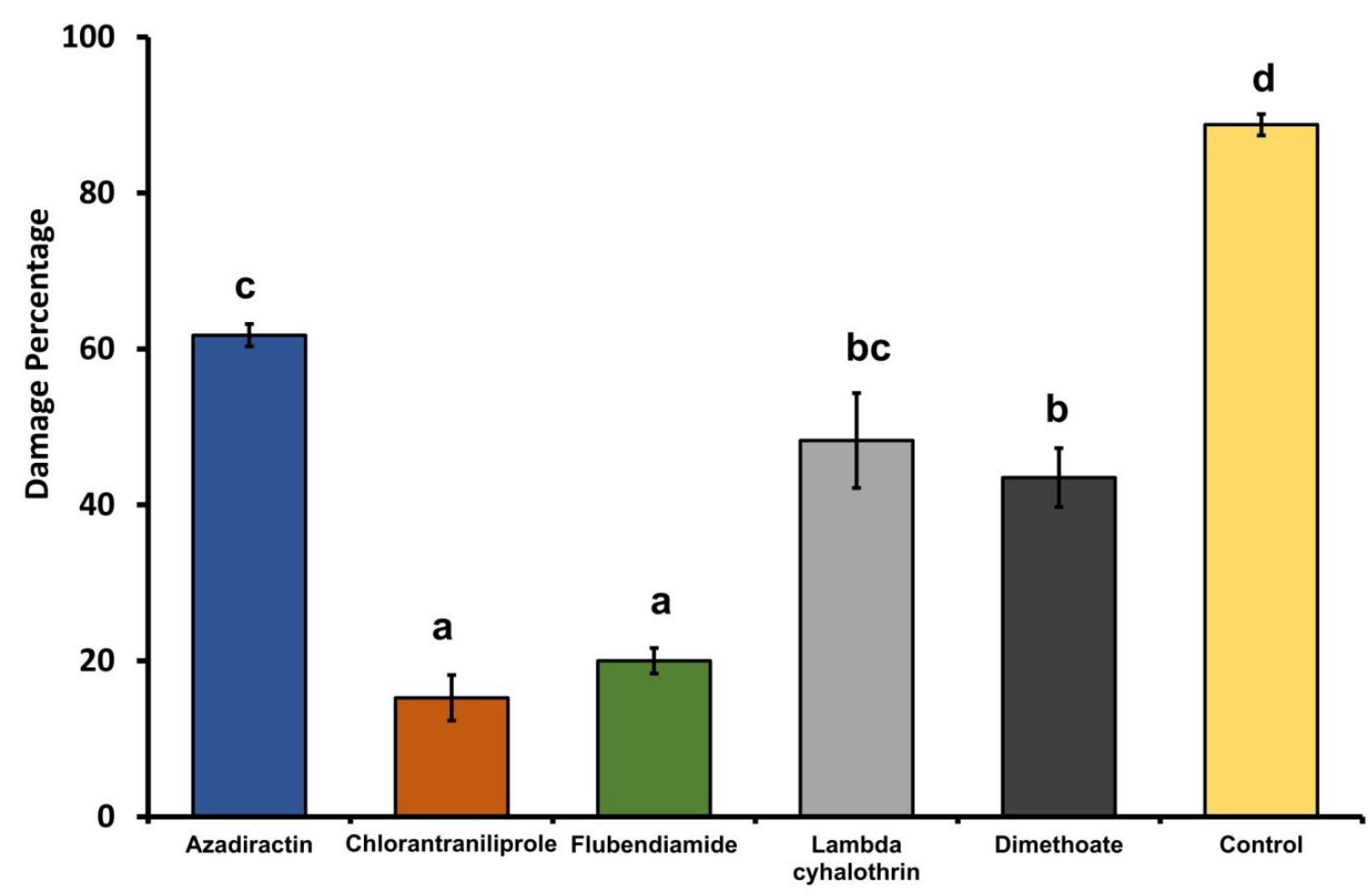

Figure 2. Mean percentage damage of Conopomorpha sinensis on Litchi in 2016 on Regional Agricultural Research Station (RARS), Tarahara, Sunsari (Bars with same letter for each treatment represents the damage was not significantly difference at $P<0.05 \%)$.

\section{DISCUSSION}

Chlorantraniliprole was found to be effective in our study which was also revealed by various researchers for the management of borers (Larrain et al 2014, Rajavel et al 2011, Coslor et al 2018, Huang et al 2016). Rajavel et al (2011) showed chlorantraniliprole effectiveness against brinjal shoot and fruit borer; Larrain et al (2014) proved its effectiveness for Tuta absoluta in tomato; Coslor et al (2018) when injected chlorantraniliprole in the apple trunk found moderate to high mortality of Choristoneura rosaceana. Similar result was found on rice stem borer, Chilo suppressalis (Walker) (Huang et al 2016). Chlorantraniliprole is a novel anthranilic diamide insecticide, effective for control of lepidopteran insect pests, as well as some species in the orders coleoptera, diptera, and hemiptera (Hannig et al 2009). Lai et al (2012) and Han et al (2012) reported that chlorantraniliprole sublethal concentration effect on development of Spodoptera exigua and Plutella xylostella. Based on feeding cessation and reduction in feeding damage, chlorantraniliprole and flubendiamide is among the fastest-acting insecticides available for control of Lepidopteran pests (Hannig et al 2009, Tohnishi 2005).

Our result showed that flubendiamide was also found effective against $C$. sinensis with low damage rate in both year. Devi and Singh (2016) reported that flubendiamide was effective against yellow stem borer Scirophaga incertulas walker. Similarly, Dhaka et al (2015) and Deshmukh et al (2010) found less damage caused by pod borer, Helicoverpa armigera (hubner) in vegetable pea, legume pod borer Maruca vitrata (Geyer) in pigeonpea (Sreekanth et al 2015), spotted stem borer, Chilo partellus (Swinhoe) (Lepidoptera: Crambidae) in maize (Arunkumara et al 2017) when treated with flubendiamide. Vijayraghavendra and Basavangoud (2017) when treated sapota with the flubendiamide found that the yield was significantly higher than control against sapota fruit borer, Phycita erythrolophia.

Khushwaha and Painkara (2016) reported that both chlorantraniliprole and flubendiamide was found effective in managing Leucinodes orbonalis and suggested that these insecticide could be used in integrated pest management system. The percent infestation in our result varied from 12 to $85.5 \%$ in 
2015 whereas it ranged from 15.25 to $88.75 \%$ in 2016. Srivastava (2017) study was in line with our study where he found the infestation of the insect up to $59.35 \%$ on dropped fruit.

However, neem-based insecticide was not found effective against $C$. sinensis. Similar result was found in legume pod borer, Maruca vitrata Fabricius (Lepidoptera: Pyralidae) and Fruit Borers of Guava (Psidium guajava L.) (Yule and Srinivasan 2013; Kaul and Yogesh 2003). Dimethoate was not found effective in our result however Drouin and wong (1975) reported that it was found effective against poplar borer Saperda calcarate, it may be effective against stem borer than fruit borer. Our result suggests either of chlorantraniliprole or flubendiamide could be used to minimize damage and loss caused by $C$. sinensis. Selectivity of the chlorantraniliprole and flubendiamide have more towards the insect ryanodine receptor (Lahm et al 2009) thus have low mammalian toxicity (Tohnishi 2005, EFSA 2013).

\section{CONCLUSION}

Best on our results we conclude that litchi fruit borer, a major pest of litchi could be managed by application of chlorantraniliprole $(18.5 \% \mathrm{w} / \mathrm{w} \mathrm{SG})$ or flubendiamide $(39.3 \% \mathrm{~m} / \mathrm{m})$. Both pesticide could be applied @ $1 \mathrm{ml}$ per 3 liter of water. It should be applied at least 3 times with 10 days interval. Since these insecticides have selective activity against insects than mammalian receptors, it may reduce the health risk to human and livestock health .

\section{ACKNOWLEDGEMENTS}

Authors would like to thank Nepal Agricultural Research Council for funding and providing the logistics to the project. We also like to acknowledge Regional Agricultural Research Station, Tarahara management team for providing the congenial environment to conduct the experiment.

\section{REFERENCES}

Anwar A, JM Mari, MA Khanzada and F Ullah. 2015. Efficacy of insecticides against infestation of brinjal fruit borer, Leucinodes orbonalis Guenee (Pyralidae: Lepidoptera) under field conditions.

Journal of Entomology and Zoology Study. 3:292-295

Arunkumara CG, M Bheemanna and HM Shaila. 2017. Field evaluation of insecticides for management of spotted stem borer, Chilo partellus (Swinhoe) (Lepidoptera: Crambidae) on maize. Journal of Entomology and Zoology Study. 5:1719-1723

Coslor CC, , C Vandervoort and JC Wise. 2018. Insecticide dose and seasonal timing of trunk injection in apples influence efficacy and residues in nectar and plant parts. Pest Management Science. 75:1453-1463. DOI: https://doi.org/10.1002/ps.5268

Deshmukh SG, BV Sureja, DM Jethva and VP Chatar. 2010. Field efficacy of different insecticides against Helicoverpa armigera (Hubner) infesting chickpea. Legume Research. 33:269-73.

Devi PR and KI Singh. 2016. Efficacy of new molecules against yellow stem borer (ysb) Scirpophaga incertulas walker under rice crop ecosystem of manipur valley. International Journal of Environment Science. 5:525-532

Dhaka SS, G Singh, A Yadav, M Rai and A Kumar. 2015. Efficacy of novel insecticides against pod borer, Helicoverpa armigera (Hubner) in vegetable pea Horticulture Journal. 47:146-150.

DOI : http://10.5958/2249-5258.2015.00025.1

Drouin JR, HR Wong. 1975. Biology, damaged, and chemical control of the poplar borer (Saperda calcarate) in the junction of the root and stem of balsam poplar in western Canada. Canadian Journal of Forest Research. 5:433-439. DOI: https://doi.org/10.1139/x75-060

EFSA. 2013. Conclusion on the peer review of the pesticide risk assessment of the active substance Flubendiamide. European Food Safety Authority (EFSA) Journal. 11:3298

FDD. 2008. Fruit Development Directorate. Government of Nepal, Ministry of Agriculture Development, Department of Agriculture, Kirtipur, Nepal.

Feng S, M Li, F Wu, W Li, and S and S Li. 2015. 5-Aminolevulinic acid affects fruit coloration, growth, and nutrition quality of Litchi chinensis Sonn. cv. Feizixiao in Hainan, tropical China. Scientia Horticulturae. 193:188-194. DOI: https://doi.org/10.1016/j.scienta.2015.07.010

Han WS, SF Zhang, FY Shen, M Liu, CC Ren and XW Gao. 2012. Residual toxicity and sublethal effects of chlorantraniliprole on Plutella xylostella (Lepidoptera: Plutellidae). Pest Management Science. 68:11841190. DOI: https://doi.org/10.1002/ps.3282 
Hannig GT, M Ziegler and PG Marcon. 2009. Feeding cessation effects of chlorantraniliprole, a new anthranilic diamide insecticide, in comparison with several insecticides in distinct chemical classes and mode-ofaction groups. Pest Management Science. 65:969-974. DOI: https://doi.org/10.1002/ps.1781

Huang C, Chang C, KSand and YI Chu. 1994. Damage and population fluctuation of the litchi fruit borer, Conopomorpha sinesnis Bradley, in Chia-Nan district, Taiwan. Plant Protection Bulletin Taipei. 36:85-95.

Huang L, Lu M, G Han, Y Dua and J Wanga. 2016. Sublethal effects of chlorantraniliprole on development, rep roduction and vitellogenin gene $(\mathrm{CsVg})$ expression in the rice stem borer, Chilo suppressalis Pest Manage ment Science. 72:2280-2286. DOI: https://doi.org/10.1002/ps.4271

IRAC. 2019. Mode of Action classification scheme. Version 9.3. IRAC International MoA Working Group. Cro p Life International. p30.

Javaregowda and LK Nalk. 2005. Bio-efficacy of flubendiamide 20 WDG (RIL-038) against paddy pests and their natural enemies. Pestology. 29:58-60.

Kaul V and K K Yogesh. 2003. Incidence and Management of Lepidopteran Fruit Borers of Guava (Psidium guajava L.) in Jammu, India. Journal Asia-Pacific Entomology. 6:201-205. DOI: https://10.1016/S12268615(08)60187-9

Kuldeep, SK Rahman Md and S Ram. 2004. Effect of sub lethal doses of lufenuron against Spodoptera litura Fab. and Spilarctia obliqua Walk. Indian Journal of Entomology. 66: 287-292.

Kumar A, K Srivastava, RK Patel and V Nath. 2014. Management of litchi fruit borer and litchi mite using biorational approaches under subtropics of Bihar. Ecoscan Special Issue. 6:285-289.

Kushwaha TK and Gopal PDP. 2016. Efficacy of certain insecticides against shoot and fruit borer (Leucinodes orbonalis gune.) On kharif season Brinjal (Solanum melongena L.) under field condition. International Journal of Agricultural Science and Research. 6:383-388.

Lahm GP, D Cordova and JD Barry. 2009. New and selective ryanodine receptor activators for insect control. Bioorganic and Medicinal Chemistry. 17:4127-4133. DOI: https://doi.org/10.1016/j.bmc.2009.01.018

Lai T and JY Su. 2011. Effects of chlorantraniliprole on development and reproduction of beet armyworm, Spodoptera exigua (Hubner). Journal of Pest Science. 84:381-386.

Larrian P, C Escudero, J Morre, and J Rodriguez. 2014. Insecticide effect of cyantraniliprole on tomato moth Tuta absoluta Meyrick (Lepidoptera: Gelechiidae) larvae in field trials. Journal of Agricultural research. 74:178-183. DOI: http://10.4067/S0718-58392014000200008

Li, P, B Chen, Y Dong, Q Yao, S Xu, K Chen, and G Chen. 2014. Effects of Temperature on Emergence Dynamics of Conopomorpha sinensis (Lepidoptera: Gracillariidae). Florida Entomologist. 97:1093-1098. DOI: https://doi.org/10.1653/024.097.0314

Masanori T, Hayami N and Fujioka S 2005. Flubendiamide, a novel insecticide highly effective against lepidopteran insect pests. Journal of Pesticide Science. 30: 354-360. DOI: https://doi.org/10.1584/jpestics.30.354

Menzel C. 2002. The lychee crop in Asia and the Pacific. Bangkok RAP Publication 20216, Regional Office for Asia and The Pacific, Food and Agriculture Organization of The United Nations, Bangkok, Thailand.

MoAD, 2016. Statistical information on Nepalese Agriculture (2015/16). Monitoring, Evaluation and Statistical Division, Agri Statistics Section, MoAD, GoN, Singhdurbar, Nepal.

Qi S and JE Casida. 2013. Species differences in chlorantraniliprole and flubendiamide insecticide binding sites in the ryanodine receptor. Pesticide Biochemistry and Physiology 107:321:326

Rajavel DS, A Mohanraj, K Bharathi. 2011. Efficacy of chlorantraniliprole (Coragen 20SC) against brinjal shoot and fruit borer, Leucinodes orbonalis (Guen.). Pest Management in Hort. Ecosystems 17:28- 31.

Schulte MJ, K. Martin and J. Sauerborn. 2007. Biology and control of the fruit borer, Conopomorpha sinensis Bradley on litchi (Litchi chinensis Sonn.) in northern Thailand. Journal Insect Science. 14:525-529.

Singh G, V Nath, SD Pandey, PK Ray and HD Singh. 2012. The Litchi. Food and agriculture Organization of the United Nations, New Delhi, India. Rome. Italy. pp 217.

SPSS. 2016. Command Syntax Reference. Polar Engineering and Consulting. SPSS Inc. 233 South Wacker Driv e, 11th Floor Chicago, IL 60606-6412.

Sreekanth. M, MSM Lakshmi and YR Koteswara. 2015. Efficacy and economics of certain new generation novel insecticides against legume pod borer, Maruca vitrata (Geyer) on pigeonpea (Cajanus cajan L.). Journal of Applied Biology and Biotechnology. 3:7-10. DOI: http://10.7324/JABB.2015.3302

Srivastava K and V Nath. 2015. Keeping emerging litchi pests under changing climate at bay. Indian Journal of Horticulture. 60:28-30.

Srivastava K, RK Patel, A Kumar, SD Pandey, PVR Reddy and V Nath. 2017. Integrated management of litchi fruit and shoot borer (Conomorpha sinensis) using insect growth regulators under subtropics of Bihar. Indian Journal of Agricultural Sciences. 87:99-102

Srivastava K and V Nath. 2015. Keeping emerging litchi pests under changing climate at bay. Indian Journal of Horticulture. 60:28-30. 
Thanh VN, DA Hai and MA Lachance. 2006. Cryptococcus bestiolae and Cryptococcus dejecticola, two new yeast species isolated from frass of the litchi fruit borer Conopomorpha sinensis Bradley. FEMS Yeast Research. 6:298-304. DOI: https://doi.org/10.1111/j.1567-1364.2006.00023.x

Tohnishi M, H Nakao, T Furuya, A Seo, H Kodama, K Tsubata, T Nishimatsu. 2005. Flubendiamide, a Novel Insecticide Highly Active against Lepidopterous Insect Pests. Journal of Pesticide Science. 30:354-360. DOI: https://doi.org/10.1584/jpestics.30.354

Tran H, HN Van, R Munjappan, J Amrine, R Naidu, R Gilbertson and J Sidhu. 2019. Interated pest management of longan (Sapindales: Sapindaceae) in Vietnam. Journal of Integrated Pest Management. 10:1-18. DOI: https://doi.org/10.1093/jipm/pmz016

Tsang W and GW Liang. 2007. Studies on rearing techniques of Conopomorpha sinensis Bradley (Lepidoptera: Gracillariidae) in laboratory (in Chinese). Natural Enemies of Insects. 29:160-165.

USDA 2019. United States Department of Agriculture. Fruits and Fruit Juices. https://fdc.nal.usda.gov/fdcapp.html\#/food-details/169086/nutrients

Vijayaraghavendra R and K Basavanagoud. 2017. Evaluation of insecticides against sapota fruit Borer, Phycita erythrolophia Hampson. Journal of Entomology and Zoology Studies. 5: 1358-1361.

Waite GK 2005 Pests. Litchi and Longan, Botany, Production and Uses (eds. C.M. Menzel \& G.K. Waite), pp. 237-259. CAB International, Wallingford.

Xiang Meng X, J Hu, Y Li, J. Dai, M Guo and G Ouyang. 2018. The preference choices of Conopomorpha sinensis Bradley (Lepidoptera: Gracilariidae) for litchi based on its host surface characteristics and volatiles. Scientific Report. 8(1).

Yule S, and R Srinivasan. 2013. Evaluation of bio-pesticides against legume pod borer, Maruca vitrata Fabricius (Lepidoptera: Pyralidae), in laboratory and field conditions in Thailand. Journal of AsiaPacific Entomology 16:357-360. DOI: https://doi.org/10.1016/j.aspen.2013.05.001<smiles></smiles> 